\title{
Toxic Effect of Glyphosate-Pesticide on Lipid Peroxidation Superoxide Dismutase and Catalase of Clarias Gariepinus
}

\section{Helen Nwamba Ogochukwu}

Department of Applied Biology and Biotechnology, Enugu State University of Science and Technology, Ebeano, Agbani, Enugu State, Nigeria

\section{Cosmas Ezekaibeya Achikanu (Corresponding Author)}

Department of Applied Biochemistry, Enugu State University of Science and Technology, Ebeano, Agbani, Enugu State, Nigeria PMB 01660

Email: cosmasachikanu@gmail.com

\begin{abstract}
The oxidative stress indices lipid peroxidation (LPO), superoxide dismutase (SOD) and catalase (CAT) in juvenile Clarias gariepinus (average weight $200.15 \mathrm{~g}$ ) exposed to sub - lethal dose $2.40 \mathrm{mg} / \mathrm{L}$ and $4.98 \mathrm{mg} / \mathrm{L}$ of glyphosate was investigated over a period of days 1,5,10 and 15 in three replicates. The colorimetric analysis showed increase in lipid peroxidation from $4.55 \pm 2.14^{\mathrm{a} 1}$ to $12.12 \pm 10.00^{\mathrm{a} 1}$ at $2.40 \mathrm{mg} / \mathrm{L}$ but remain the same at $4.98 \mathrm{mg} / \mathrm{L}\left(4.55 \pm 2.14^{\mathrm{a} 1}\right) \mathrm{compared}$ with control $\left(3.03 \pm 0.01^{\mathrm{a} 1}\right.$ to $\left.1.51 \pm 2.14^{\mathrm{b} 1}\right)$ from day 1 to 15 . The SOD activity decreased significantly with time and concentration compared with control. The Catalase activity at day 15 decreased to $0.17 \pm 0.05^{\text {a1 }}$ in $2.40 \mathrm{mg} / \mathrm{L}$ but further increased to $0.28 \pm 0.05^{\mathrm{b} 1}$ in $4.98 \mathrm{mg} / \mathrm{L}$ compared to $0.28 \pm 0.02 \mathrm{a}$ l catalase activity as control. The result suggests that glyphosate induce oxidative stress that may overwhelm the antioxidant system in juvenile catfish especially at higher concentrations with long exposure.
\end{abstract}

Keywords: Toxicity; Glyphosate; Clarias gariepinus; Oxidative stress.

\section{Introduction}

Mans wholesome activities which are geared towards the provision of a better life for him have created severe imbalance in our ecosystem [1]. One of the important factors contaminating the natural habitat is agricultural pesticides. Though the use of herbicides to control weeds has been recognised worldwide as part of agricultural practices to improve agricultural production, the indiscriminate use of these herbicides, careless handling, accidental spillage or discharge of untreated effluents into natural water ways have harmful effects on the fish population and other aquatic organisms and may contribute to long term effects in the environment [2]. Glyphosate: $N$ (phosphonomethyl)-glycine is an organophosphorus compound that exerts a non selective but broadspectrum systemic herbicidal effect [3]. It is specifically a phosphonate used to kill weeds, especially annual broadleaf weeds and grasses that compete with crops and it is also a crop desiccant [4]. As an analogue of phospoenolpyruvate, it inhibits the plant enzyme 5-enolpyruvylshikimate-3-phosphate synthase that catalyses the reaction of shikimate-3-phosphate (S3P) and phosphoenol pyruvate to form 5-enolpyruvyl-shikimate-3-phosphate (ESP) [5]. In recent years, concern have increased worldwide about the potential wide ranging direct and indirect health effects of the large scale use of glyphosate [6].Xenobiotics like pesticides undergo several biochemical reactions generating reactive oxygen species which induce lipid peroxidation, alter cellular redox status and causes certain disease conditions associated with aging [7]. An imbalance in the production of reactive oxygen species and cellular antioxidant system results in oxidative stress leading to damages of the cells [8]. Amongst aquatic organisms, fishes are frequently employed as models in understanding oxidative stress in aquatic environments [9] and since they can bioaccumulate pollutants they can be used as biomarkers of aquatic pollution Plessi, et al. [10] and [11]. In this work we aim to determine the response of oxidative stress indices in juvenile Clarias gariepinus exposed to sub-lethal concentration of glyphosate.

Clarias gariepinus is catfish located in Africa, the middle East, Brazil and Indonesia. It is of the Claridae family and found in fresh water, lakes, rivers and swamps and human made habitats such as oxidative ponds and urban sewage system. The adult fish has average length of $1-1.5 \mathrm{~m}$ and can weigh up to $60 \mathrm{~kg}$ with flat body head, broad terminal mouth with four pairs of barbels and large accessory breathing organs made up of modified gill arches [12].

\section{Materials and Methods}

\subsection{Experimental Fish and Acclimatization}

A total of 100 juveniles of C.gariepinus were obtained from Rojenny tourist game village, Idemili LGA. Anambra state, Nigeria and transported in well aerated 300 litre capacity plastic containers to Heildin fisheries 
laboratory unit in Enugu state, Nigeria. The fish were acclimatised to laboratory conditions for 14 days and fed with commercial feed $(6 \mathrm{~mm}$ coppens fish feed for agriculture). The container was cleaned, dead fish removed and the water changed every morning. The fish was not fed for 48 hours before and during the exposure time. A set of 10 experimental fish specimen was randomly exposed to different concentrations $(18.5,25.9$ and $33.3 \mathrm{mg} / \mathrm{L})$ of glyphosate in 10 litres of dechlorinated and aerated tap water to determine the 96hour lethal concentration (96h $\mathrm{LC}_{50}$ ) value. Based on the $\mathrm{LC}_{50}$ of glyphosate at 96hours, the effect of the sub-lethal concentrations of 2.40 and 4.98 $\mathrm{mg} / \mathrm{L}$ on the oxidative stress parameters for $1,5,10$ and 15 days were determined with sets of 10 fish in triplicate. The control is fish in tap water without glyphosate.

\subsection{Asessment of Lipid Peroxidation (LPO)}

The LPO estimation was done using thiobarbituric acid reactive substance assay according to Buege and Aust [13]. Liver homogenate sample of $(0.1 \mathrm{ml})$ was added to $0.1 \mathrm{ml}$ of $150 \mathrm{mM}$ Tris- $\mathrm{HCl}(\mathrm{pH} 7.1), 1.5 \mathrm{mM}$ ascorbic acid and $1 \mathrm{mM}$ ferrous sulphate in a final volume of $1 \mathrm{ml} 10 \%$ trichloroacetic acid (TCA) and $2 \mathrm{ml} \mathrm{of} 0.375 \%$ thiobarbituric acid were added and kept in boiling water for 15minutes. The content was centrifuged at 3000rpm for 10 minutes and the optical density was measured at 532 and $600 \mathrm{~nm}$.

$$
\mathrm{LPO}=\{[(532-600) \mathrm{nm} / 0.066] * 2 * 10\} \mathrm{mg} / 100 \mathrm{~g}
$$

\subsection{Assessment of Superoxide Dismutase}

$1.2 \mathrm{ml}$ of solution A (50mM Dismutase (SOD), sodium carbonate in $0.1 \mathrm{mM}$ EDTA buffer, pH10.8), $0.5 \mathrm{ml}$ of solution B $\left(96 \mu \mathrm{M}\right.$ nitroblue tetrazolium - NBT) and $0.1 \mathrm{ml}$ of solution $\mathrm{C}(0.6 \%$ Triton $\mathrm{x}-100)$ were incubated at $37^{\circ} \mathrm{C}$ for 10 minutes with the reaction initiated by adding $0.1 \mathrm{ml}$ of $20 \mathrm{mM}$ hydroxylamine HCL (pH6.0). The rate of NBT dye reduced by $\mathrm{O}_{2}{ }^{-}$anion generated due to photoactivation of hydroxylamine HCL was recorded at 560nm for 3 minutes as blank while the SOD activity was determined by adding $0.1 \mathrm{ml}$ post mitochondrial supernatant (PMS) immediately after addition of hydroxylamine HCL to the reaction mixture, mixed thoroughly and the $50 \%$ inhibition in the rate of nitroblue tetrazolium (NBT) reduction by SOD present in the enzyme source was recorded at $560 \mathrm{~nm}$ for 3minutes [14].

\subsection{Assessment of Catalase}

The assay mixture used were made up of $2.9 \mathrm{ml}$ of $12.5 \mathrm{mM} \mathrm{H}_{2} \mathrm{O}_{2}, 0.067 \mathrm{M}$ phosphate buffer $(\mathrm{pH} 7.0)$ and $0.01 \mathrm{ml}$ post mitochondrial supernatant (PMS) while distilled water is the blank. The decrease in absorbance/30sec at $240 \mathrm{~nm}$ was measured for 3 minutes $[15,16]$.

Catalase Activity $(\mathrm{k})=(2.303 / \Delta \mathrm{T}) \alpha\left(\log \mathrm{A}_{1} / \mathrm{A}_{1} \mathrm{~A}_{2}\right) \mathrm{k} / \mathrm{min}$

\subsection{Statistical Analysis}

The statistical data were shown as the mean \pm sem. The significant differences of the data were analysed using analysis of variance (ANOVA) from SPSS statistical package (version 17).

\section{Results}

From table 1; Lipid peroxidation (LPO) values increased from $3.03 \pm 0.01^{\text {al }}$ to $4.55 \pm 2.14^{\text {al }}$ at 2.40 and $4.98 \mathrm{mg} / \mathrm{L}$ glyphosate in Dayl respectively. There was also further increase in peroxidation in Day15 from $1.51 \pm 2.14^{\mathrm{b} 1}$ to $12.12 \pm 0.00^{\mathrm{a} 1}$ at $2.40 \mathrm{mg} / \mathrm{L}$ and $4.54 \pm 2.14^{\mathrm{a} 1}$ at $4.98 \mathrm{mg} / \mathrm{L}$ glyphosate compared to control respectively. Within the exposure time, $2.40 \mathrm{mg} / \mathrm{L}$ glyphosate induced peroxidation reaction more $\left(4.55 \pm 2.14^{\mathrm{a} 1}\right.$ to $\left.12.12 \pm 0.00^{\mathrm{a} 1}\right)$ unlike the $4.98 \mathrm{mg} / \mathrm{L}$ glyphosate where the reaction was the same compared with the control.

Superoxide dismutase (SOD) activity significantly decreased from $0.28 \pm 0.00^{\mathrm{b} 1}$ to $0.03 \pm 0.02^{\mathrm{b} 2}$ at $2.40 \mathrm{mg} / \mathrm{L}$ and $0.29 \pm 0.01^{\text {al }}$ to $0.04 \pm 0.01^{\mathrm{b} 2}$ at $4.98 \mathrm{mg} / \mathrm{L}$ with time and concentration of glyphosate compared with control $0.49 \pm 0.02^{\mathrm{a} 1}$ to $0.05 \pm 0.01^{\mathrm{a} 1}$.

Catalase (CAT) value significantly decreased from $0.44 \pm 0.07^{\mathrm{a} 1}$ to $0.17 \pm 0.05^{\mathrm{a} 1}$ at $2.40 \mathrm{mg} / \mathrm{L}$ and $0.51 \pm 0.19^{\mathrm{b} 1}$ to $0.28 \pm 0.05^{\mathrm{b} 1}$ at $4.98 \mathrm{mg} / \mathrm{L}$ compared to the control $\left(0.22 \pm 0.14^{\mathrm{a} 1}\right.$ to $\left.0.28 \pm 0.02^{\mathrm{al}}\right)$ with time. The CAT values significantly increased in days 1 to 10 compared with the control as the concentration of glyphosate increased. At day 15 , the CAT activity remain the same as control at $4.98 \mathrm{mg} / \mathrm{L}$

\section{Discussion}

Reactive oxygen species [4] which include hydrogen peroxide $\left(\mathrm{H}_{2} \mathrm{O}_{2}\right)$, superoxide anion and hydroxyl radicals are generated by many mechanisms in organisms under physiological conditions [17, 18].Pesticide can induce production of ROS which results in lipid peroxidation, protein oxidations, modulation of gene expression, alterations of redox status and certain disease conditions [7, 19]. The peroxidation of lipid is particularly damaging because of the formation of aldehyde - products of $\omega 3$ and $\omega 6$ of polyunsaturated fatty acid [17]. In this present study we demonstrated that increasing the concentration of glyphosate induced lipid peroxidation significantly compared with the control. Prolonged exposure to glyphosate increased lipid peroxidation significantly at $2.40 \mathrm{mg} / \mathrm{L}\left(4.55 \pm 2.14^{\mathrm{a} 1}\right.$ to $\left.12.12 \pm 0.00^{\mathrm{a} 1}\right)$ compared with control $\left(3.03 \pm 0.01^{\mathrm{a} 1}\right.$ to $\left.1.51 \pm 2.14^{\mathrm{b} 1}\right)$. Though further increase in the concentration of gyphosate to $4.98 \mathrm{mg} / \mathrm{L}$ increased peroxidation reaction to $4.55 \pm 2.14^{\mathrm{a} 1}$ compared with control, there was no change ultimately in the lipid peroxidation with time (Table 1). Previous works reported elevated lipid peroxidation in fish exposed to different herbicides [20, 21] and other toxicants [22, 23]. 
Through different mechanisms, reactive oxygen species [4] are generated continually and antioxidant enzymatic systems protect the organisms from the toxic effects of the free radicals by scavenging the ROS [24](. Superoxide dismutase (SOD) enzymes which are crucial and acts everywhere as antioxidant that check the steady-state levels of $\mathrm{O}_{2} \cdot{ }^{-}$[25] protect the cells from the lethality of superoxide radical [26]. The data in this study showed that the SOD was inhibited significantly with increase in concentrations of glyphosate and time. Yin, et al. [27], reported altered SOD activity in Chinese toad tadpoles exposed to spirotetramat within 15 days. Excessive production of free radicals and raised hydrogen peroxide level in the cell may damage the SOD protein whereby inducing inhibition of SOD activity [28].The catabolism of hydrogen peroxide by Catalase decreased significantly within the 15 days exposure of the juvenile catfish at both sub-lethal concentrations of glyphosate. Mekail and Sharafaddin [29], reported decreased activity in CAT with weaning rats treated with diazinon, carbaryl and cyhalothrin. However, with increase in concentration of glyphosate, the catalase activity increased at days 1 and 10 significantly compared with the control. Radovanović, et al. [30], reported an increase in CAT activities of adult green toad exposed to delthamethrin.

In this work, increase in peroxidation of lipids indicates that the rate in production of reactive oxygen species may have increased [31]. These ROS can induce oxidation of biomolecules whereby damaging compounds such as proteins, nucleic acids, and lipids if not scavenged by the antioxidant system [32]. Direct damage of protein (SOD and CAT) structure by ROS generated by glyphosate in this work may be responsible for the decrease in activities of the antioxidants. Moreover, due to limited capacity of the antioxidants in fish to neutralise the effects of the free radicals, production of ROS may overwhelm their removal in the tissues and cells of exposed subjects [33, 34].

\section{Conclusion}

This result suggests the exposure of catfish to the sublethal concentrations of glyphosate over time will activate lipid peroxidation and alter the antioxidant system with the onset of oxidative damage of macromolecules perhaps due to the overwhelming presence of reactive oxygen species generated.

Table-1. The values of oxidative stress indices of Clarias gariepinus exposed to different concentrations of Glyphosate

\begin{tabular}{l|l|l|l|l}
\hline Oxidative stress indicators & Day 1 & Day 5 & Day 10 & Day 15 \\
\hline LPO Mg/100g & & & & \\
\hline Control & $3.03 \pm 0.01^{\mathrm{al}}$ & $4.54 \pm 2.14^{\mathrm{al}}$ & $3.03 \pm 0.00^{\mathrm{al}}$ & $1.51 \pm 2.14^{\mathrm{bl}}$ \\
\hline $2.40 \mathrm{mg} / \mathrm{L}$ & $4.55 \pm 2.14^{\mathrm{al}}$ & $3.03 \pm 0.00^{\mathrm{a} 2}$ & $6.06 \pm 8.57^{\mathrm{bl}}$ & $12.12 \pm 0.00^{\mathrm{al}}$ \\
\hline $4.98 \mathrm{mg} / \mathrm{L}$ & $4.55 \pm 2.14^{\mathrm{al}}$ & $6.06 \pm 0.00^{\mathrm{al}}$ & $3.03 \pm 0.00^{\mathrm{bl}}$ & $4.54 \pm 2.14^{\mathrm{al}}$ \\
\hline SOD K/min & & & & \\
\hline Control & $0.49 \pm 0.02^{\mathrm{al}}$ & $0.48 \pm 0.01^{\mathrm{b} 2}$ & $0.78 \pm 0.38^{\mathrm{bl}}$ & $0.05 \pm 0.01^{\mathrm{al}}$ \\
\hline $2.40 \mathrm{mg} / \mathrm{L}$ & $0.28 \pm 0.00^{\mathrm{bl}}$ & $0.02 \pm 0.01^{\mathrm{b} 2}$ & $0.27 \pm 0.01^{\mathrm{bl}}$ & $0.03 \pm 0.02^{\mathrm{b} 2}$ \\
\hline $4.98 \mathrm{mg} / \mathrm{L}$ & $0.29 \pm 0.01^{\mathrm{al}}$ & $0.19 \pm 0.01^{\mathrm{a} 2}$ & $0.24 \pm 0.24^{\mathrm{b} 2}$ & $0.04 \pm 0.01^{\mathrm{b} 2}$ \\
\hline Catalase k/min & & & & \\
\hline Control & $0.22 \pm 0.14^{\mathrm{al}}$ & $0.37 \pm 0.17^{\mathrm{bl}}$ & $0.22 \pm 0.70^{\mathrm{bl}}$ & $0.28 \pm 0.02^{\mathrm{al}}$ \\
\hline $2.40 \mathrm{mg} / \mathrm{L}$ & $0.44 \pm 0.07^{\mathrm{al}}$ & $0.41 \pm 0.14^{\mathrm{al}}$ & $0.69 \pm 0.13^{\mathrm{bl}}$ & $0.17 \pm 0.05^{\mathrm{al}}$ \\
\hline $4.98 \mathrm{mg} / \mathrm{L}$ & $0.51 \pm 0.19^{\mathrm{bl}}$ & $0.32 \pm 0.02^{\mathrm{bl}}$ & $0.46 \pm 0.19^{\mathrm{bl}}$ & $0.28 \pm 0.05^{\mathrm{bl}}$ \\
\hline
\end{tabular}

The values with different alphabetic (lower case) superscripts differ significantly $(P<0.05)$ between different exposure periods within the same concentration. Values with different numeric superscripts differ significantly $(P<$ $0.05)$ between different concentrations within the same exposure duration.

\section{References}

[1] Battaglin, W. A., Dana, W. K., Elizabeth, A. S., Kathryn, M. N., and Mark, W. S., 2002. "Glyphosphate, other herbicide and transformation products in midwestern stream." Journal of the African Water Resources Association, vol. 91, pp. 323-332.

[2] Nwani, C. D., Naresh, S. N., Ravindra, K., Basdea, K., Pavan, K., and Wazir, S. L., 2010a. "Lethal concentration and toxicity stress of carbosulfan, glyphosate and atrazine to fresh water air breathing fish Channapuctatus (Bloch)." Aquatic Retrive, vol. 2, pp. 105-111.

[3] Piesova, E., 2005. The effect of glyphosate on the frequency of micronuclei in bovine lymphocytes invitro vol. 55. Biograd: Acta veterinarai. pp. 101-109.

[4] Marrs, R. H., Frost, A. J., Plant, R. A., and Lunnis, P., 1993. "Determination of buffer zones to protect seedlings of non-target plants from the effects of glyphosate spray drift." Agriculture, Ecosystems and Environment, vol. 45, pp. 283-293.

[5] Williams, G. M., Kroes, R., and Munro, I. C., 2000. "Safety evaluation and risk management of the herbicide roundup and its active ingredient, glyphosate for humans." Regulatory Toxicology and Pharmaclogy, vol. 31, pp. 117-165.

[6] Van Bruggen, A. H. C., He, M. M., Shin, K., Mai, V., Jeong, K. C., Finckh, M. R., and Morris, J. G. J., 2018. "Environmental and health effects of the herbicide glyphosate." Science of The Total Environment vol. 616-617, pp. 255-268.

[7] Blanco-Ayala, T., Anderica-Romero, A. C., and Pendraza-Chaverri, J., 2014. "New insights into antioxidant strategies against paraquat toxicity." Free Radicals Research, vol. 48, pp. 623-640. 
[8] Weidinger, A. and Kozlov, A. V., 2015. "Biological activities of reactive oxygen and nitrogen species: Oxidative stress versus signal transduction." Biomolecules, vol. 5, pp. 472-484.

[9] Dautremepuits, C., Pares-palacios, S., Betoulle, S., and Vernet, G., 2004. "Modulation in hepatic and head kidney parameters of carp (cyprimus carpio 1) induced by copper and chitosan. Comparative biochemistry and physiology part c: Toxicology." Pharmacology, vol. 137, pp. 325-333.

[10] Plessi, C., Otachi, E. O., Korner, W., Avenant-Oldewage, A., and Jirsa, F., 2017. "Fishes bioindicators for trace element pollution from two contrasting lakes in the Eastern rift valley, Kenya: spatial and temporal aspects." Environmental Science and Pollution Research, vol. 24, pp. 19767-19776.

[11] Ramírez-Ayala, E., Arguello-Pérez, M. Á., Ilizaliturri-Hernández, C. A., Tintos-Gómez, A., MejíaSaavedra, J., and Borja-Gómez, I., 2018. "A brief review of the use of biomarkers in Mexico's aquatic ecosystems pollution assessment: 2001-2017." Lat. Am. J. Aquat. Res., vol. 46, pp. 860-879.

[12] Sambhu, C., 2004. "African catfish, clarias gariepinus (Burchell, 1822): An ideal candidate for biowaste management." Indian Journal of Experimental Biology, vol. 42, pp. 1226-1229.

[13] Buege, J. A. and Aust, S. D., 1978. "Microsomal lipid peroxidation." Methods in Enzymology, vol. 52, pp. 302-310.

[14] Kono, Y., 1978. "Generation of the superoxide radical during antioxidation of hydroxylamine and an assay for superoxide dismutase." Archives in Biochemistry Biophysics, vol. 186, pp. 189-195.

[15] Luck, H., 1971. Bergmeyer ho (ed), catalase, methods of enzymatic analysis. New York: Academic Press. p. 855.

[16] Sinha, A. K., 1972. "Colometric assay on catalase." Analytical Biochemistry, vol. 47, pp. 389-394.

[17] Park, J. H., Park, Y. S., Lee, J. B., Park, K. H., Paik, M. K., and Jeong, M., 2016. "Meloxican inhibits fipronil-induced apoptosis via modulation of the oxidative stress and inflammatory response in SH-SY5Y cells." Journal of Applied Toxicology, vol. 36, pp. 10-23.

[18] Chandra, K., Syed, S. A., Abid, M., Sweety, R., and Najam, A. K., 2015. "Protection against induced oxidative stress, induced DNA damage as a model of arthritis and in vitro anti-arthritic potential of costusspeciosus rhizome extract." International Journal of Pharmacognosy and Phytochemical Research, vol. 7, pp. 383-389.

[19] Zhou, J., Li, J., Yuan, H., and Yu, F., 2012. "Study on a new synthesis approach of glyphosate." Journal of Agricultural and Food Chemistry, vol. 60, pp. 6279-6285.

[20] Blahova, J., Plhalova, L., and Hostovosky, M., 2013. "Oxidative stress responses in zebra fish Dianoreri after sub-chronic exposure to atrazine." Food chemistry and toxicology, vol. 61, pp. 82-85.

[21] Modesto, K. A. and Martinez, C. B., 2010. "Effects of roundup transport of fish; hematology, antioxidant defences and acetylcholinesterase activity." Chemosphere, vol. 81, pp. 781-787.

[22] Adeyemi, J. A., 2014. "Oxidative stress and antioxidant enzyme activities in the Africana catfish Clarias gariepinus,experimentally challenged with Escherichia coli and Vibrio fishcheri." Fish physiology and Biochemistry, vol. 40, pp. 347-354.

[23] Brandao, F. P., Rodrigues, S., Castro, B. B., Gonclaves, F., Antunes, S. C., and Nunes, B., 2013. "Shortterm effects of neuro-active pharmaceutical drugs on a fish species: Biochemical and behavioural effects." Acquatic Toxicology, pp. 218-229.

[24] Schafer, F. Q. and Buettner, G. R., 2001. "Redox environment of the cell as viewed through the redox state of the glutathione disulfide/glutathione couple. Free Radical." Biology and Medicine, vol. 30, pp. 11911212.

[25] Batinic, H. I., Tovmasyan, A., Roberts, E. R. H., Vujaskovic, Z., Leong, K. W., and Spasojevic, I., 2014. "Sod therapeutics: Latest insights into their structure-activity relationships and impact on the cellular redoxbased signaling pathways." Antioxidants and Redox Signalling, vol. 20, pp. 2372-2415.

[26] Ejilibe, C. O., Nwamba, H. O., Ani, C. L., Madu, J., Onyishi, G. C., and Nwani, C. D., 2018. "Oxidative stress responses in bufo regularis tadpole exposed to butaforce and termex." Journal of Fisheries and Livestock Production, vol. 6, pp. 1-5.

[27] Yin, X., Yu, S. J., Zhu, G. N., Wu, M. H., and Mao, G., 2014. "Effects of spirotetramat on the acute toxicity, oxidative stress and lipid peroxidation in Chinese toad (Bufo bufogargarizans) tadpoles." Environmental Toxicology and Pharmacology, vol. 37, pp. 1229-1235.

[28] Ahmad, I., Pacheco, M., and Santos, M. A., 2004. "Enzymatic and non-enzymatic antioxidants as an adaptation to phagocyte-induced damage in Anguilla anguilla L. following in situ harbor water exposure." Ecotoxicology and Environmental Safety, vol. 57, pp. 290-302.

[29] Mekail, A. and Sharafaddin, Z. A., 2009. "A study on the activity of catalase and glutathione-s-transferase in weaning and adult rats intoxicated with diazinon,carbaryl and lambda-cyhalothrin." In Proceedings of 2nd Kurdistan conference on Biological Sciences. pp. 138-145.

[30] Radovanović, T. B., Nasia, M., Krizmanić, I. I., Prokić, M. D., and Gavrić, J. P., 2017. "Sub- lethal effects of the pyrethroid insecticides deltamethrin on oxidative stress parameters in green toad (bufotes viridis 1.)." Environ Toxicol Chem, vol. 36, pp. 2814-2822.

[31] Pandey, A. K., Nagpure, N. S., and Trivedi, S., 2011. "Profenofos induced DNA damage in freshwater fish Channa punctatus (Bloch) using alkaline single cell gel electrophoresis." Mutational Research, vol. 726, pp. 209-214. 
[32] Kelly, S. A., Havrilla, C. M., Brady, T. C., Abramo, K. H., and Levin, E. D., 1998. "Oxidative stress in toxicology; Established mammalian and emerging piscine model systems." Environmental Health Perspestives, vol. 106, pp. 375-384.

[33] Dabas, A., Nagpure, N. S., and Kumar, R., 2011. "Assessment of tissue specific effect of cadmium on antioxidant defense system and lipid peroxidation in freshwater murrel, Channapuntatus." Fish Physiology and Biochemistry, vol. 38, pp. 469-482.

[34] Trenzado, C., Hidalgo, M. C., Gallego, M. G., Morales, A. E., and Furne, M., 2006. "Antioxidant enzymes and lipid peroxidation in sturgeon Acipenser naccarri and trout Onchorhynchus mykiss, a comparative study." Aquaculture, vol. 254, pp. 758-767. 